\title{
Low Boreal Wetlands as a Source of Atmospheric Methane
}

\author{
NIGEL T. ROULET AND ROSEMARY ASH
}

Department of Geography, York University, North York, Ontario

TIM R. MOORE

Department of Geography, McGill University, Montreal, Quebec, Canada

\begin{abstract}
Boreal wetlands are thought to be a large source of atmospheric methane, but this idea is based on very few measurements. Thus a regional survey in the low boreal forest region of central Ontario, Canada, consisting of 24 sites over 12 wetlands and 3 beaver ponds was conducted to determine the temporal and spatial trends in emissions and the net annual methane $\left(\mathrm{CH}_{4}\right)$ flux. Conifer swamps represented nearly $50 \%$ of the wetland coverage, but emit a small amount of $\mathrm{CH}_{4}$ (seasonal means $<8 \mathrm{~m} \mathrm{~m}^{-2} \mathrm{~d}^{-1}$ ). The significant emitters of $\mathrm{CH}_{4}$, in order from highest to lowest seasonal means, were beaver ponds $\left(30-90 \mathrm{mg} \mathrm{m}^{-2} \mathrm{~d}^{-1}\right)$, thicket swamps $\left(0.1-88 \mathrm{mg} \mathrm{m}^{-2} \mathrm{~d}^{-1}\right)$, and bogs $\left(6-21 \mathrm{mg} \mathrm{m}^{-2} \mathrm{~d}^{-1}\right)$. Mixed swamps, marshes, and fens emitted very little $\mathrm{CH}_{4}\left(<3 \mathrm{mg} \mathrm{m}^{-2} \mathrm{~d}^{-1}\right)$. Moisture saturation was the key determinant of high emissions, and when satisfied, differences in emissions could be explained by peat and sediment temperatures. On the basis of the areal extent of wetlands from peatland inventories we calculate that the low boreal region of Canada contributes approximately $0.15 \mathrm{Tg} \mathrm{CH}_{4} \mathrm{yr}^{-1}$ to the atmosphere. This is an order of magnitude lower than the flux would be using the estimate of Aselmann and Crutzen (1989) for the same boreal region.
\end{abstract}

\section{INTRODUCTION}

To maintain the present atmospheric concentration of methane (1.8 $\mathrm{ppm}(\mathrm{v}))$ and current rate of increase of $1 \% \mathrm{yr}^{-1}$, a source size between 500 and $550 \mathrm{Tg} \mathrm{CH}_{4}$ is required annually [Cicerone and Omerland, 1988; Crutzen, 1991]. Present estimates suggest approximately $20 \%$ contribution from each of wetlands, rice paddies, ruminants, and anthropogenic sources. The remaining $20 \%$ is made up of smaller sources such as biomass burning, termites, and the extraction and transport of fossil fuels [Cicerone and Omerland, 1988]. The largest concentration of wetlands is in the northern hemisphere between $40^{\circ}$ and $70^{\circ} \mathrm{N}$, covering the ecological regions of the cool temperate, boreal, and subarctic forest zones. While estimates vary, this zone may contribute between approximately 30 [Aselmann and Crutzen, 1989] and $80 \mathrm{Tg} \mathrm{CH}_{4} \mathrm{yr}^{-1}$ [Matthews and Fung, 1987] to the atmosphere, representing between 6 and $16 \%$ of all sources. The large discrepancies in the flux estimates from wetlands in this zone are the result of relatively few $\mathrm{CH}_{4}$ flux measurements, differences in the estimated coverage of wetlands, and the duration of the flux period. There is a need for $\mathrm{CH}_{4}$ flux estimates for wetlands in this region from a diverse set of climatic, physiographic, and ecological settings. This paper presents the results of a study that examined the methane flux from wetlands representative of low boreal forest region of North America.

Two approaches have been suggested for the regional extrapolation of flux estimates [Matson and Vitousek, 1990]:(1)

Copyright 1992 by the American Geophysical Union.

Paper number 91JD03109.

0148-0227/92/91JD-03109\$05.00 remotely sense the temporal and spatial changes in the variables that correlate with methane emissions and then compute the fluxes and (2) measure the annual flux from representative wetlands and then areally weight the regional flux according to the fractional area coverage of each wetland type obtained from remote sensing [e.g. Bartlett et al., $1989 a, b]$, and existing wetland inventories. The lack of a single clear environmental correlate for $\mathrm{CH}_{4}$ emissions that holds across wetland types, even within a given region [Crill et al., 1988; Moore et al., 1990; Yavitt et al., 1990], may preclude the first approach for $\mathrm{CH}_{4}$ flux extrapolation. Regional estimates using the second approach, linear extrapolation, have compared successfully with estimates of $\mathrm{CH}_{4}$ obtained using towers and aircraft [Bartlett et al., 1989; Roulet, 1991]. These studies used remote sensing (Spot and Landsat thematic mapper) to derive the wetland inventory, but when remote sensing is not available because of such factors as cost, lack of ground truthing, or low resolution, previous wetland inventories may be a suitable alternative. In the present study we used the results of the Ontario Peatland Inventory [Riley and Michaud, 1987; Riley, 1988] to determine the wetland coverage. Existing inventories can also be used to establish a priori the relative frequency of occurrence of wetlands, and this can be used to stratify the $\mathrm{CH}_{4}$ sampling program.

Most studies of methane emissions have been designed to determine the spatial and temporal variability of the flux within one or two wetlands of a given region [Crill et al., 1988; Moore and Knowles, 1989; Moore et al., 1990]. These studies have shown that the intrawetland variability can be as great as the interwetland variability. To quantify the annual $\mathrm{CH}_{4}$ source strength from a given wetland type, the sample size has to be large enough to reduce the standard error to an acceptable level [Bartlett et al., 1989a; Moore and Roulet, 1991] and the sampling program has to run long enough to cover the 
entire emission season [Whalen and Reeburgh, 1988; Moore and Knowles, 1989].

The objective of the present study was to determine the net contribution to the atmosphere of $\mathrm{CH}_{4}$ emitted from wetlands in the low boreal forest region of central Canada. This information can be used to strengthen the estimates of the role of wetlands at the global scale [Matthews and Fung, 1987; Aselmann and Crutzen, 1989; Fung et al., 1991]. Wetlands sampled in the study included open and treed bogs, open fens, and conifer, mixed, and thicket swamps, marshes, and beaver ponds. Methane emissions were measured from each wetland for the snow-free period of 1990.

\section{STUDY AREA, SITES AND METHODS}

\subsection{Study Area}

Measurements of the $\mathrm{CH}_{4}$ flux from 12 wetlands and 3 beaver ponds located in a $625-\mathrm{km}^{2}$ area of the low boreal forest region [National Wetlands Working Group (NWWG), 1988] of central Canada $\left(45^{\circ} 04^{\prime} \mathrm{N}, 7^{\circ} 45^{\prime} \mathrm{W}\right)$, were made from May to October 1990 (Figure 1: Energy, Mines, and Resources Canada [1986a,b]). This region was selected because of a wide variety of undisturbed wetlands within close proximity to each other. The study area is located on the southern limit of the Precambrian Canadian shield. Wetlands and beaver ponds are typically small $(<10 \mathrm{ha})$ and are located in depressions between low relief hills of exposed metamorphic silicate bedrock with areas of shallow basal till overburden approximately $1 \mathrm{~m}$ thick. The upland forests surrounding the wetlands were once dominated by eastern white pine but were logged in the late 1800 s. The uplands are now dominated by a mix of red pine, trembling aspen, balsam poplar, white birch, and red maple. The climate of the region is classified as humid microthermal [Energy Mines and Resources, 1990]. The mean annual temperature for the nearest climate station (Dorset, Ontario) is $4.4^{\circ} \mathrm{C}$, and the mean annual total precipitation is $1102 \mathrm{~mm}$, of which $25 \%$ falls as snow. The snow-free period extends from late April to late October. The mean daily temperature and total precipitation for the 1990 snowfree period were $13.7^{\circ} \mathrm{C}$ and $436 \mathrm{~mm}$, which represent normal temperatures but $24 \%$ less precipitation than average.

\subsection{Wetlands of the Study Area and Sample Design}

The wetlands of the low boreal forest zone are described by Riley and Michaud [1987], Riley [1988], and the NWWG [1988]. Conifer swamps are the dominant wetland type of this forest region (Table 1 and Figure 1). These are usually nutrient-rich, minerotrophic wetlands, with moderately deep peats $(1.8-2.9 \mathrm{~m})$. Common tree species are northern white cedar and tamarack (larch), and typical shrubs are swamp birch and Labrador tea. Mixed hardwood-conifer swamps are more common on the southern fringe of the region than in the more northern portion (Table 1). In mixed swamps, northern white cedar and balsam fir represent the conifers, while black ash, balsam poplar, white birch, American elm, and red maple are the codominant deciduous species. The peat depth in mixed swamps ranges from 1.4 to $1.7 \mathrm{~m}$. Thicket swamps display a greater variability in peat depths $(0-2.8 \mathrm{~m})$ and vegetation cover than that of swamps. Common shrubs are bog willows, red-osier dogwood, speckled alders, and swamp

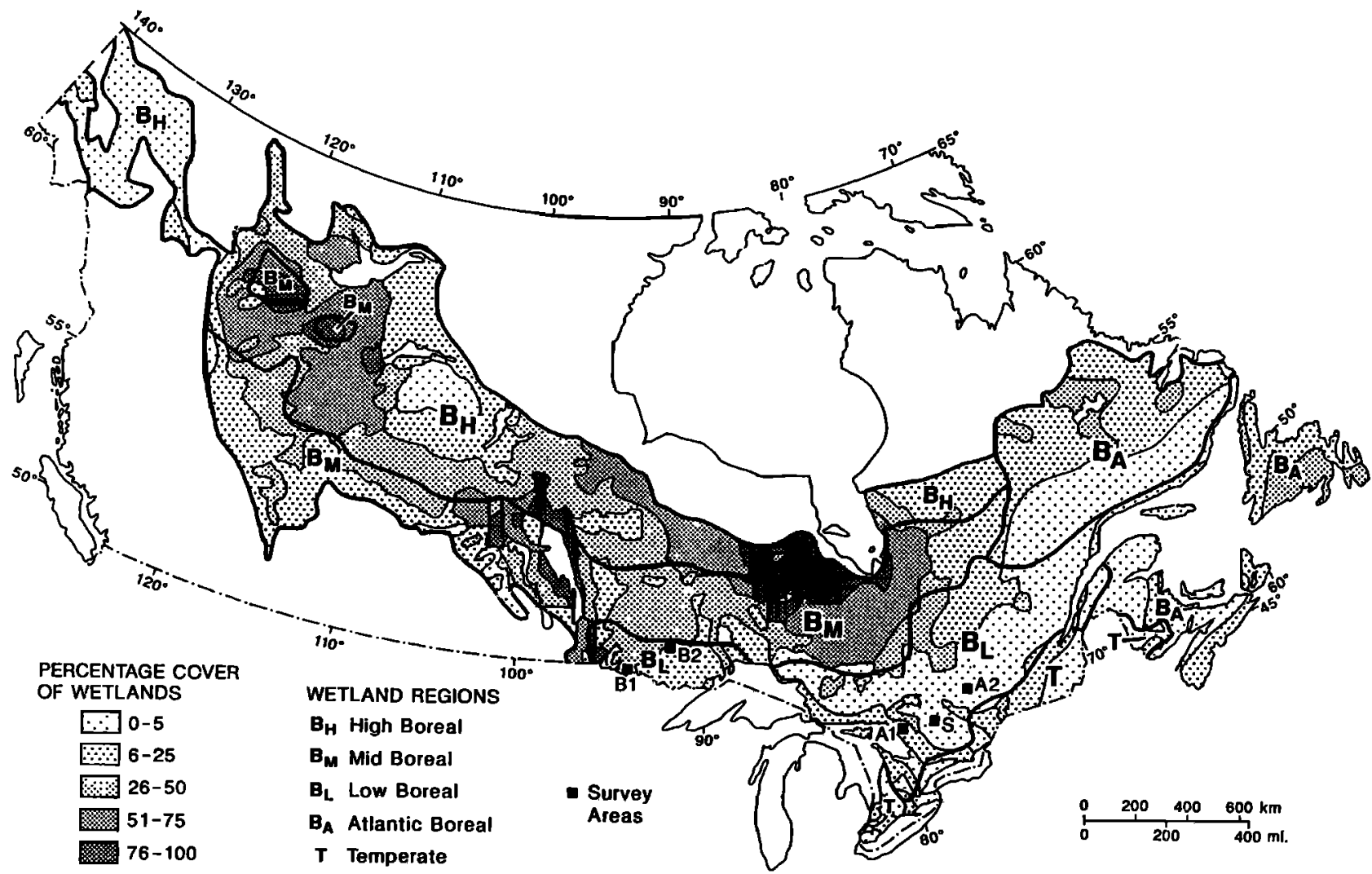

Fig. 1. The wetland regions and percent wetland coverage in the boreal forest region of Canada. The solid squares indicate the areas of the low boreal wetland region that Riley and Michaud [1987] (B1 and B2) and Riley [1988] (A1 and A2) conducted in the peatland inventories. $S$ is the location of the sampling area used in the present study. 
TABLE 1. Percent Coverage by Wetland Type Based on the Inventories of Southeastern and Northwestern Ontario by Riley and Michaud [1987] and Riley [1988] for areas in the low boreal forest region

\begin{tabular}{lccccccccc}
\hline \multicolumn{1}{c}{ Region } & $\begin{array}{c}\text { Area Mapped } \\
\text { ha }\end{array}$ & Bog & Fen & $\begin{array}{c}\text { Conifer } \\
\text { Swamp }\end{array}$ & $\begin{array}{c}\text { Hardwood and } \\
\text { Mixed Swamp }\end{array}$ & $\begin{array}{c}\text { Thicket } \\
\text { Swamp }\end{array}$ & Marsh & $\begin{array}{c}\text { Percent of Total } \\
\text { Area }\end{array}$ \\
\hline Pembroke & 577,000 & 1.0 & 0.2 & 54.5 & 15.0 & 15.8 & 14.0 & 13.5 \\
Parry Sound & 750,000 & 22.6 & $\ldots$ & 47.9 & 16.0 & 8.9 & 4.7 & 6.8 \\
Rainy River & 460,000 & 25.2 & 16.7 & 19.6 & 5.2 & 16.7 & 6.5 & 25.2 \\
Ignace & $1,600,000$ & 24.3 & 20.2 & 43.8 & 0.0 & 6.8 & 5.1 & 12.1 \\
Means & & 18.3 & 9.3 & 41.5 & 9.1 & 14.6 & 7.6 & 14.4 \\
\hline
\end{tabular}

birch and tend to occur in clusters on slightly raised hummocks (10 - $30 \mathrm{~cm}$ high, $1-3 \mathrm{~m}$ diameter). The hummocks are separated by 1 -to 2 -m-wide depressions that usually contain flowing water. The marshes contain numerous graminoid and herbaceous species and usually have shallow peats $(<1.0 \mathrm{~m})$. Open bogs, treed bogs and fens occur less frequently in the low boreal region, although bogs are more common in the northern portion. Treed and open bogs usually have a welldeveloped peat layer $(>2.0 \mathrm{~m})$, with a surface cover of either graminoids (Carex spp.) or mosses (Sphagnum spp.), and both are covered with shrubs such as leatherleaf and pale laurel. On treed bogs the most common tree species are black spruce and tamarack. Fens are infrequent, and treed fens are rare. Fens have a diverse cover of shrubs (e.g. birch, sweet gale, narrowleaf Spirea, and bog willow) and graminoids and herbs (e.g. royal fern, sedges, and dewberry).

In this region there are also many small, shallow water bodies ( $<1 \mathrm{ha},<1.0 \mathrm{~m}$ ) that have been created by beavers [Novak, 1987]. Many ponds are relatively free of vegetation; however, some older ponds which usually have been abandoned have emergent and floating marcophytes typical of many marshes (rushes, water lilies, and cattails).

The wetlands sampled for $\mathbf{C H}_{4}$ flux were stratified according to the percent cover of each wetland type determined by Riley and Michaud [1987] and Riley [1988] (Table 2). Because of the availability of wetlands in the area, some wetland types were slightly oversampled or undersampled relative to the regional estimates.

\subsection{Sampling the Methane Flux From the Wetlands}

On each wetland at least five static chambers were used. In some wetlands, where there were two distinct hydrological regimes, such as flooded depressions and dry hummocks, two sites of five chambers each were established. The static chambers were made of $18 \mathrm{~L}$ polycarbonate bottles $(26 \mathrm{~cm}$ diameter; $40 \mathrm{~cm}$ height; area of exposure, $0.053 \mathrm{~m}^{2}$ ), from which the bases were removed. The bottle neck was sealed with a rubber stopper which contained a glass tube with a rubber septum stopper. Chambers were covered with aluminum foil to minimize heating. The chambers were gently inserted $2 \mathrm{~cm}$ into the peat at nonflooded sites. At flooded sites the lower lip of the chamber was placed $2 \mathrm{~cm}$ below the water surface. The volume of air in the chamber was corrected for the displacement caused by the placement of the chambers. With a large regional sampling program such as the one used in this study it was not feasible to use collars. Initial chamber concentrations were taken after the chambers were inserted, and if the samples were elevated above ambient concentrations ( $>2 \mathrm{ppm}$ ), the sample was rejected. This approach resulted in a $20 \%$ sample rejection rate, therefore redundance had to be built into the program. The chambers

TABLE 2. The Sampling Program for Methane Measurements

\begin{tabular}{lcccc}
\hline Wetland Type & $\begin{array}{c}\text { No. of Wetlands } \\
\text { Studied }\end{array}$ & $\mathrm{N}^{\mathrm{a}}$ & $\begin{array}{c}\text { Percent of Total } \\
\text { Sample }\end{array}$ & $\begin{array}{c}\text { Percent Cover } \\
\text { From Riley }\end{array}$ \\
\hline Conifer swamps & 4 & 540 & $32(35)^{\mathrm{c}}$ & 42 \\
Hardwood/mixed swamps & 2 & 286 & $17(19)$ & 9 \\
Thicket swamps & 2 & 289 & $17(19)$ & 15 \\
Bogs, treed and open & 1 & 133 & $8(09)$ & 18 \\
Fens, treed and open & 1 & 62 & $4(04)$ & 9 \\
Marshes & 2 & 207 & $12(14)$ & 8 \\
Beaver ponds & 3 & 186 & $\ldots$ & $\ldots$ \\
\hline
\end{tabular}

\footnotetext{
${ }^{\mathrm{a}}$ Number of methane flux measurements.

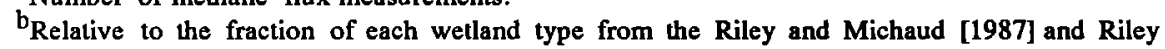
[1988] welland surveys from Table 1.

${ }^{c}$ In parentheses are the fraction of samples relative to the total wetland samples minus those of beaver ponds for direct comparison with Table 1 .
} 
on the beaver ponds were floated in styrofoam collars and suspended away from the shore.

Chambers were set up on the afternoon of the first day of a weekly survey and sampled the next morning. Fluxes were determined over a period ranging from 16 to 24 hours. In a subarctic fen, Moore and Roulet [1991] found concentrations increased linearly over 24 hours from wetlands with fluxes 2 to 3 times larger than those observed in this study. Samples were obtained by inserting a needle attached to a $10-\mathrm{mL}$ syringe into the septum stopper. The piston of the syringe was pumped 5 times to mix the air in the chamber before a $10-\mathrm{mL}$ sample was drawn. When a sample run was completed, the chambers were removed from the immediate location of the site and left to be used the following week. Samples were transported back to the laboratory and analyzed within 24 hours.

Methane concentrations were analyzed on a Shimadzu Mini2 gas chromatograph with a flame ionization detector and a 1$\mathrm{mL}$ injection loop. The column was Poropak-Q (80/100 mesh, $3 \mathrm{~m}$ by $3 \mathrm{~mm}$ ) which was kept at $40^{\circ} \mathrm{C}$. Helium was used as a carrier gas at a flow rate of $30 \mathrm{~mL} \mathrm{~min}$. Standards of 2 and $200 \mathrm{ppm}(\mathrm{v})$ were used to calibrate the gas chromatograph.

\subsection{Ancillary Environmental Variables}

Groundwater wells were installed at each site to monitor the height of the water table and to sample water for chemical analysis. Wells were constructed of $3.5 \mathrm{~cm}$ ID ABS pipe, $1.5 \mathrm{~m}$ in length with the lower $1.25 \mathrm{~m}$ perforated. Water tables were measured first, then the well was pumped and the water discarded. After the well recharged, a $50-\mathrm{mL}$ water sample was placed in a plastic bottle and was transported back to the laboratory and stored at $4^{\circ} \mathrm{C}$ until analyzed; $\mathrm{pH}$ was measured immediately using a Hanna Instruments model HI

TABLE 3. Mean ( \pm Standard Deviation) Water Chemistry, Water Table, and Temperature of the Study Wetlands and Beaver Ponds

\begin{tabular}{|c|c|c|c|c|c|c|c|c|c|c|c|c|}
\hline Wetland & $\mathrm{pH}$ & & $\mathrm{Ca}$, & $\mathrm{mg} \mathrm{L}^{-1}$ & Mg, & $\mathrm{mg} \mathrm{L}^{-1}$ & EC, & $\mu S \mathrm{~cm}^{-1}$ & WT, & $\mathrm{cm}$ & $T_{10}$ & ${ }^{\circ} \mathrm{C}$ \\
\hline BP1 & 5.2 & \pm 0.3 & 2.0 & \pm 0.2 & 0.6 & \pm 0.1 & 38.2 & \pm 14.5 & $40.0^{a}$ & & 18.3 & $\pm 5.5^{b}$ \\
\hline BP2 & 5.1 & \pm 0.4 & 3.6 & \pm 0.6 & 0.7 & \pm 0.1 & 117.9 & \pm 26.9 & 22.0 & & 21.2 & \pm 3.5 \\
\hline BP3 & 4.9 & \pm 0.3 & 1.7 & \pm 0.4 & 0.5 & \pm 0.1 & 16.5 & \pm 7.3 & 34.0 & & 19.3 & \pm 3.5 \\
\hline CS1-D & 5.5 & \pm 0.4 & 18.9 & \pm 1.7 & 4.9 & \pm 1.0 & 540.0 & \pm 149.3 & -1.9 & \pm 2.6 & 12.2 & \pm 3.2 \\
\hline CS1-H & 4.7 & \pm 0.2 & 17.6 & \pm 1.4 & 5.0 & \pm 0.4 & 452.7 & \pm 214.4 & -17.2 & \pm 5.2 & 11.6 & \pm 3.0 \\
\hline CS2-L & 5.7 & \pm 0.5 & 4.6 & \pm 0.6 & 1.5 & \pm 0.3 & 52.3 & \pm 4.3 & -7.4 & \pm 7.0 & 12.2 & \pm 3.3 \\
\hline CS2-I & 4.4 & \pm 0.2 & 3.6 & \pm 1.0 & 0.9 & \pm 0.2 & 61 & \pm 10.7 & -9.5 & \pm 6.9 & 11 & \pm 2.8 \\
\hline CS3-L & 3.9 & \pm 1.4 & 1.9 & \pm 0.8 & 0.4 & \pm 0.1 & 31.2 & \pm 10.8 & -12.9 & \pm 8.5 & 11.7 & \pm 3.0 \\
\hline CS3-I & 3.5 & \pm 1.4 & 1.6 & \pm 0.2 & 0.4 & \pm 0.0 & 40.4 & \pm 11.8 & -20.9 & \pm 8.4 & 11.6 & \pm 2.4 \\
\hline CS4-L & 4.5 & \pm 0.2 & 2.3 & \pm 1.1 & 0.5 & \pm 0.2 & 35.7 & \pm 14.8 & -10.8 & $=14.3$ & 12.4 & \pm 3.2 \\
\hline CS4-I & 3.8 & \pm 1.3 & 2.6 & \pm 1.5 & 0.4 & \pm 0.2 & 36.2 & \pm 7.9 & -7.4 & \pm 5.5 & 12.2 & \pm 3.5 \\
\hline MS1-D & 4.5 & \pm 0.4 & 9.0 & \pm 1.9 & 4.6 & \pm 0.9 & 164.7 & \pm 40.8 & -2.5 & \pm 3.7 & 12.8 & \pm 2.9 \\
\hline MS1-H & 4.8 & $\neq 0.3$ & 2.7 & \pm 0.5 & 0.9 & \pm 0.1 & 59.4 & \pm 16.8 & -7.3 & \pm 4.6 & 12.5 & \pm 2.7 \\
\hline MS2-D & 4.2 & \pm 0.2 & 1.7 & \pm 0.9 & 0.3 & \pm 0.1 & 73.2 & \pm 105.7 & -8.7 & \pm 8.4 & 12.4 & \pm 3.2 \\
\hline TS1-D & 5.5 & \pm 0.5 & 2.0 & \pm 0.3 & 0.5 & \pm 0.1 & 72.5 & \pm 39.9 & -0.2 & \pm 0.6 & 16.2 & \pm 3.8 \\
\hline TS1-H & 4.6 & \pm 0.2 & 2.2 & \pm 1.2 & 0.5 & \pm 0.2 & 38.0 & \pm 12.2 & -7.9 & \pm 4.0 & $\cdots$ & \\
\hline TS2-D & 6.0 & \pm 0.4 & 16.5 & \pm 4.0 & 3.7 & \pm 1.6 & 528.8 & \pm 274.3 & $-21.9 \pm$ & 17.6 & 13.1 & \pm 2.6 \\
\hline TS2-H & 5.9 & \pm 0.5 & 28.3 & \pm 7.4 & 9.5 & \pm 0.9 & 835.0 & \pm 359.3 & $-49.8+$ & $=32.3$ & 12.6 & \pm 2.5 \\
\hline M1-O & 5.0 & \pm 0.5 & 2.2 & \pm 0.6 & 0.5 & \pm 0.8 & 60.9 & \pm 17.1 & -5.4 & \pm 7.6 & 13.2 & \pm 3.0 \\
\hline M2-O & 5.2 & \pm 0.5 & 2.3 & \pm 1.1 & 0.6 & \pm 0.2 & 21.7 & \pm 10.7 & $-32.1+$ & 28.5 & 12.6 & \pm 3.2 \\
\hline B-T & 5.5 & \pm 0.5 & 1.9 & \pm 0.2 & 0.4 & \pm 0.1 & 27.6 & \pm 6.6 & -3.6 & \pm 5.1 & .. & . \\
\hline B-O & 4.3 & \pm 0.2 & 2.5 & \pm 0.7 & 0.8 & \pm 0.1 & 20.4 & \pm 8.2 & -2.9 & \pm 4.3 & 11.9 & \pm 2.5 \\
\hline F-O & 4.8 & \pm 1.7 & 3.3 & \pm 0.9 & 0.7 & \pm 0.2 & 116.8 & \pm 10.8 & $-11.4 \pm$ & 10.9 & 12.4 & \pm 2.6 \\
\hline
\end{tabular}

Nomenclature for siles: BP, beaver ponds; CS, conifer swamps; MS, mixed (handwood), swamps; TS, thicket swamps; M, marshes; B, bogs; F, fens; L, lagg; I, interior; D, depression; H, hummock; T, treed; and O, open.

apth of water at the site where the flux measurements were made.

${ }^{b}$ Indicates the temperature of the sediments at $10 \mathrm{~cm}$ below the sediment/water interface in the beaver ponds. 
8417 meter. Conductivity was determined using a Consort conductiviy meter model K220. The concentrations of calcium $\left(\mathrm{Ca}^{2+}\right)$ and magnesium $\left(\mathrm{Mg}^{2+}\right)$ were measured on a Varian SpectrAA-10 atomic adsorption spectrometer. Peat temperatures were taken every $10 \mathrm{~cm}$ for at least the top $50 \mathrm{~cm}$ at each site using a thermistor probe (Fenwal JA41J1).

\section{RESULTS}

The methane flux from the wetlands and beaver ponds, along with the environmental variables were obtained on 15 regional surveys conducted from May 23 (3 weeks after snowmelt) to October 22, 1990 ( 2 weeks before snow cover). Over 1700 flux measurements were made from 12 different wetlands and 3 beaver ponds.

\subsection{Environmental Setting of the Wetlands}

The wetlands studied can be classified as being mineral-poor wetlands $\left(\mathrm{Ca}^{2+}<3 \mathrm{mg} \mathrm{L}^{-1}, \mathrm{Mg}^{2+}<1.0 \mathrm{mg} \mathrm{L}^{-1}\right.$, and electrical conductivity (EC) $<50 \mu \mathrm{S} \mathrm{cm}^{-1}$ ), with the exception of one conifer swamp and one thicket swamp (Table 3). The Precambrian shield rock is low in base cations and inhibits any significant groundwater movement which could provide mineral elements to the wetlands. The higher $\mathrm{Ca}^{2+}$ and $\mathrm{Mg}^{2+}$ concentrations at two sites indicated some groundwater influence, probably from very localized deposits of glacial overburden. The fen site was moderately minerotrophic. With the exception of one thicket swamp (TS2) the wetlands ranged from moderately acidic (mixed swamps, bogs, and fens) to quite acidic (conifer swamps). The chemistry of the beaver ponds did not differ from that of the peatlands: they were moderately acidic and low in base cations (Table 3 ).

The water table in many of the wetlands was below the peat surface (Table 3). The marshes and one thicket swamp (TS2) maintained a mean water table below $-20 \mathrm{~cm}$, while the conifer swamps, mixed swamps, and fen had an average water table near $-10 \mathrm{~cm}$. The only wetlands where the water table was persistently near the surface were the other thicket swamp (TS1) and the bog. The water table of the wetlands followed four different patterns (Figure 2). The conifer and mixed swamps, fen, and marshes were surface saturated only immediately after snowmelt, then the water table quickly dropped to between -10 and $-20 \mathrm{~cm}$ for most of the summer. The water table rose slightly in autumn in some of these wetlands. The water table at the bog remained at the peat surface for May, June, and half of July, then dropped $10 \mathrm{~cm}$. Thicket swamp 1 depressions remained saturated for the duration of the study, while the water table at the hummock sites followed the trend represented by the bog. The beaver ponds remained flooded at a depth 20 to $40 \mathrm{~cm}$ at the sites where the methane flux was measured (Table 3 ).

The thermal regime of the peatlands was very similar, with the mean $-10 \mathrm{~cm}$ temperature between $12^{\circ}$ and $14^{\circ} \mathrm{C}$ (Table 3). Typical midsummer temperature gradients in the top 20 $\mathrm{cm}$ of the peatlands were $-0.6^{\circ} \mathrm{C} \mathrm{cm}^{-1}$ : below $-20 \mathrm{~cm}$ the temperature profile was near isothermal (e.g. temperature gradient of only $-5^{\circ} \mathrm{C} \mathrm{m}^{-1}$ ). The depressions at one thicket swamp (TS1) were about $2^{\circ} \mathrm{C}$ warmer on average at $-10 \mathrm{~cm}$ than the other peatlands. The most marked difference was the temperature of the sediments of the beaver ponds, which at 10 $\mathrm{cm}$ below the sediment/water interface were $19^{\circ} \mathrm{C}$, or $6^{\circ}$ to $8^{\circ} \mathrm{C}$ greater than that of the peatlands, and the temperature gradient was much less $\left(<0.015^{\circ} \mathrm{C} \mathrm{m}^{-1}\right)$. This resulted from a greater sediment heat flux in the beaver pond sediments than at the other sites. For example, the seasonal mean sediment temperature $40 \mathrm{~cm}$ beneath the sediment/water interface was $17.1^{\circ} \mathrm{C}$, while the temperature at the same depth

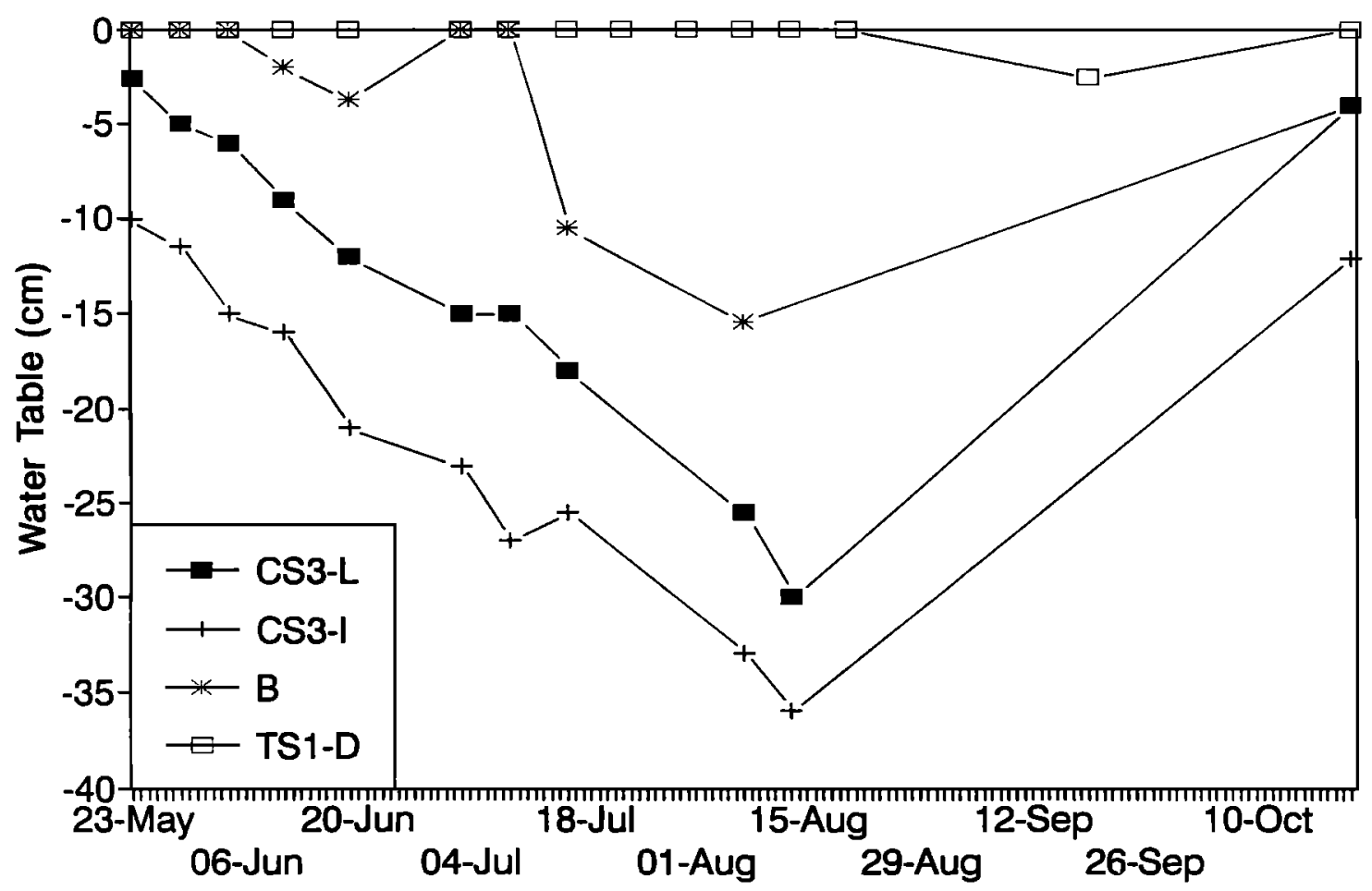

Fig. 2. The pattem of water table location for selected wetlands. CS, TS, and B signify conifer swamp, thicket swamp, and bog and I and $\mathrm{L}$ indicate interior and lagg. 

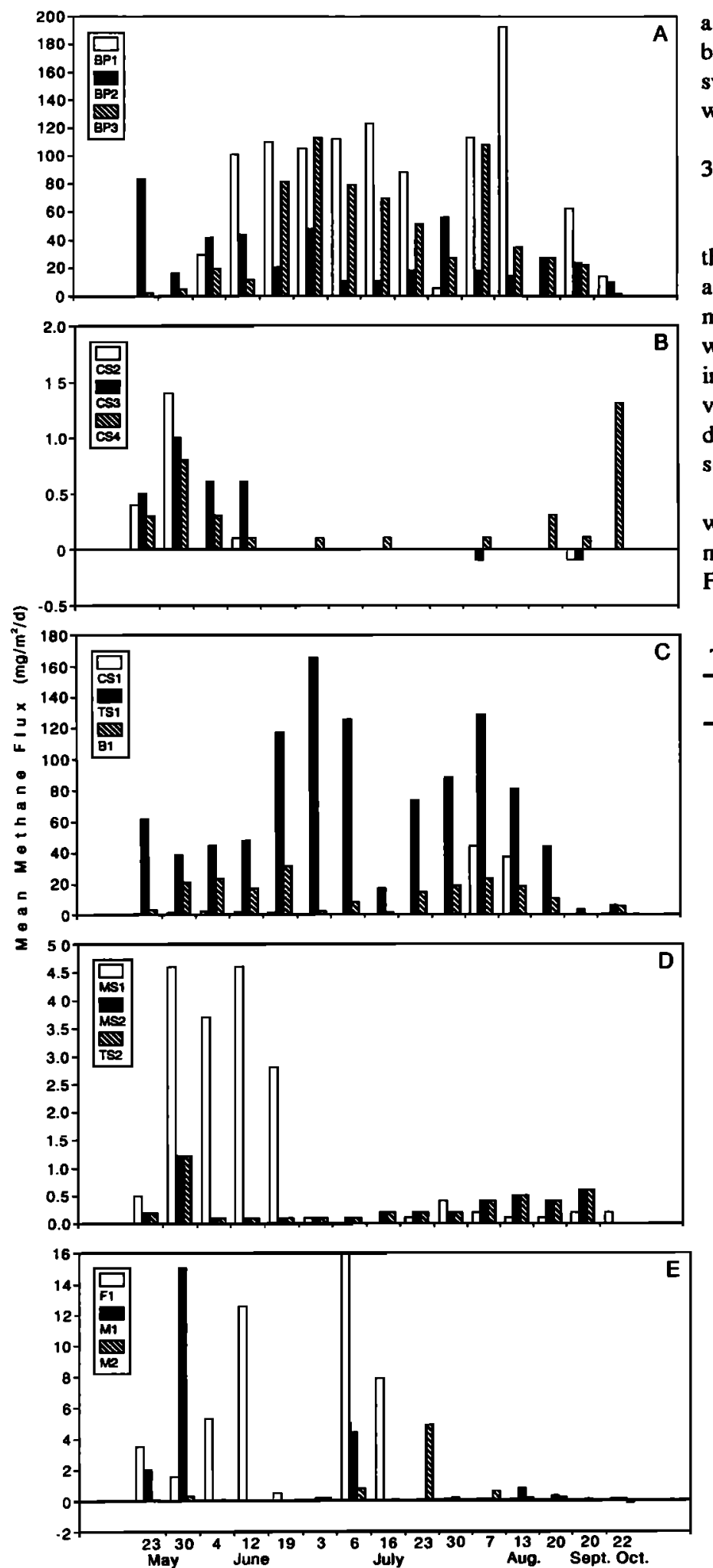

Fig. 3. Temporal trend in methane emissions from (a) beaver ponds (BP); (b) conifer swamps (CS); (c) high yielding conifer swamp 1, thicket swamp 1 (TS), and the bog (B); (d) mixed swamps (MS) and the low yielding thicket swamp; and (e) marshes (M) and the fen (F). Note the difference in vertical scale for each panel.

below the surface of the peatlands was $11.2^{\circ} \mathrm{C}$. The seasonal patterns of the peatland and sediment temperatures at $-10 \mathrm{~cm}$ are illustrated in Figure 2 . The beaver ponds had the highest maximum temperatures, while thicket swamp 2 (TS2) exhibited a higher maximum $\left(\sim 20^{\circ} \mathrm{C}\right)$ than the other peatlands. The bog temperatures are representative of the other thicket swamp, the conifer and mixed swamps, marshes, and fen, in which the maximum temperatures reached only $15^{\circ} \mathrm{C}$.

\subsection{Seasonal Trend in Methane Emissions}

There were large differences in methane emission rates from the different wetlands (Figures $3 a-3 e$ ). All fluxes reported are the mean fluxes for a given sample date based on a minimum of five samples, but in most cases the sample size was 10. Only the mean fluxes are shown, but as demonstrated in other studies [e.g. Crill et al., 1988; Moore et al., 1990], the variance was large, with coefficients of variation (standard deviation/mean) lying between 25 and 200\% (see Table 4 for seasonal variances).

The beaver ponds collectively produced the most $\mathrm{CH}_{4}$ of all wetlands sampled (Figure 3a). The seasonal pattern of the methane flux followed the warming of the sediments (see Figure 4). There were differences in the magnitude of

TABLE 4. Seasonal Methane Flux by Wetland Site ( $\mathrm{mg} \mathrm{m}^{-2} \mathrm{~d}^{-1}$ )

\begin{tabular}{lccccc}
\hline Site & Mean & \pm S.D. & Maximum & Minimum & N \\
\hline BP1 & 90.6 & 75.4 & 246.2 & 0.9 & 56 \\
BP2 & 29.7 & 44.0 & 399.5 & 0.3 & 65 \\
BP3 & 47.4 & 65.7 & 368.7 & 0.2 & 65 \\
CS1-D & 8.4 & 31.9 & 195.4 & 0.0 & 65 \\
CS1-H & 5.8 & 31.4 & 235.7 & -0.2 & 58 \\
CS2-L & 0.1 & 0.3 & 2.3 & -0.1 & 65 \\
CS2-I & 0.2 & 1.2 & 9.5 & 0.1 & 67 \\
CS3-L & 0.3 & 1.0 & 5.6 & -0.2 & 74 \\
CS3-I & 0.1 & 0.3 & 2.3 & -0.2 & 74 \\
CS4-L & 0.1 & 0.3 & 1.8 & 0.1 & 75 \\
CS4-I & 0.3 & 1.1 & 9.1 & -0.2 & 74 \\
MS1-D & 2.2 & 5.5 & 27.6 & -0.3 & 68 \\
MS1-H & 0.2 & 0.2 & 1.9 & -0.3 & 73 \\
MS2-D & 0.1 & 1.2 & 10.4 & -0.1 & 73 \\
MS2-H & 0.4 & 0.5 & 2.4 & -5.8 & 66 \\
TS1-D & 50.5 & 95.5 & 304.5 & 0.1 & 71 \\
TS1-H & 88.1 & 95.4 & 295.9 & 0.0 & 74 \\
TS2-D & 0.7 & 4.4 & 37.3 & -0.2 & 72 \\
TS2-H & 0.1 & 0.4 & 3.5 & -0.3 & 72 \\
M1-O & 1.2 & 4.6 & 36.3 & -0.1 & 72 \\
M2-0 & 0.5 & 2.5 & 25.6 & -0.3 & 134 \\
B-T & 5.8 & 16.7 & 107.4 & -0.1 & 68 \\
\hline & 20.6 & 27.8 & 140.2 & -0.1 & 65 \\
B & 3.0 & 12.3 & 78.3 & -0.2 & 62 \\
\hline
\end{tabular}

${ }^{a}$ No accompanying environmental information in Table 3. 


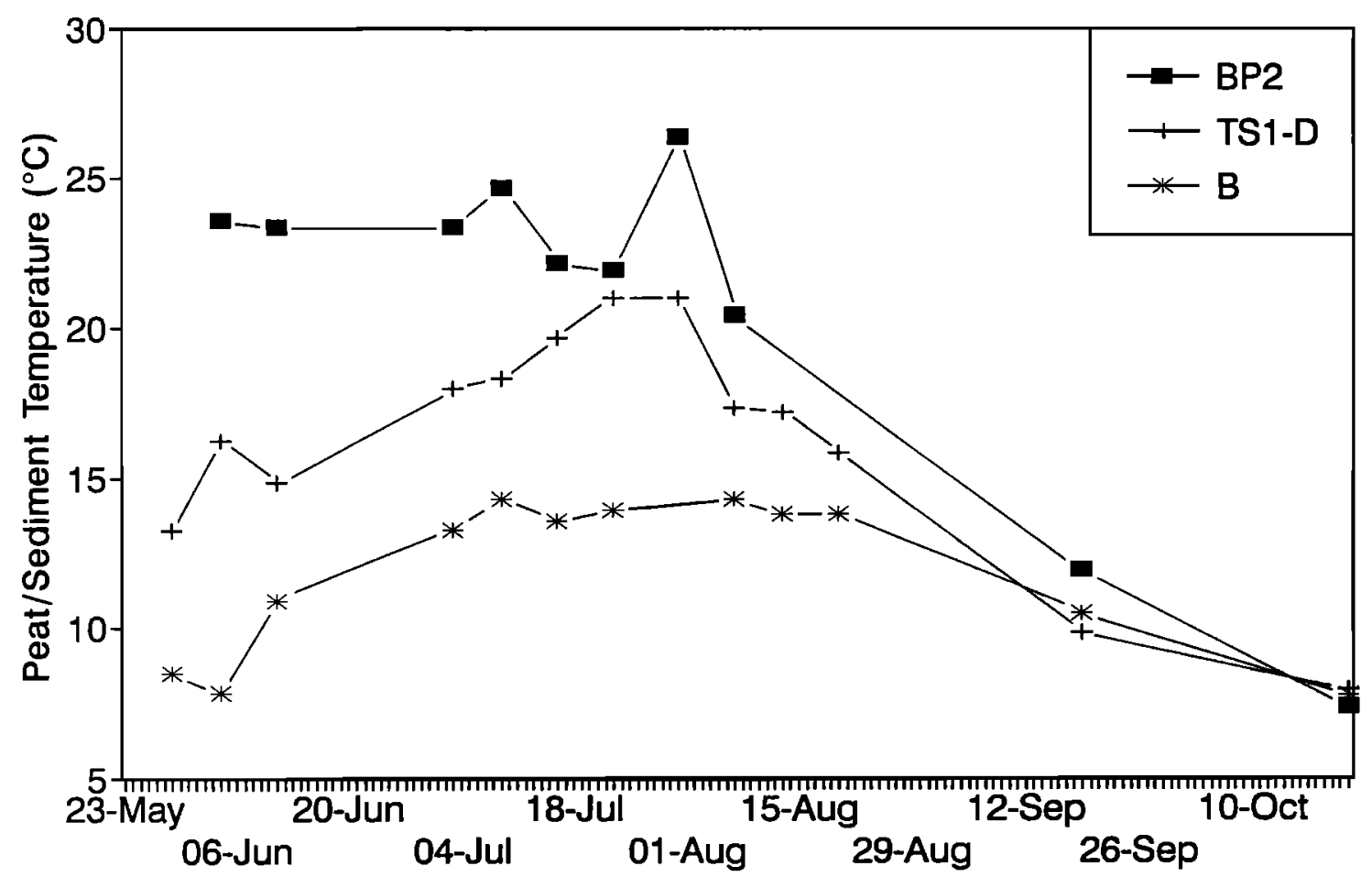

Fig. 4. The pattern of peat and sediment temperatures $(-10 \mathrm{~cm}$ depth) for selected wetlands. BP2, TS1, and B signify beaver pond, thicket swamp, and bog.

emissions between beaver ponds 1 and 3 and beaver pond 2 , the fluxes were generally $60-70 \mathrm{mg} \mathrm{CH}_{4} \mathrm{~m}^{-2} \mathrm{~d}^{-1}$ lower at beaver pond 2. Mean peak fluxes from beaver ponds 1 and 3 were greater than $100 \mathrm{mg} \mathrm{CH}_{4} \mathrm{~m}^{-2} \mathrm{~d}^{-1}$, with one exceptional mean flux of over $190 \mathrm{mg} \mathrm{CH}_{4} \mathrm{~m}^{-2} \mathrm{~d}^{-1}$ from beaver pond 1 .

While conifer swamps are the single largest wetland type in the low boreal forest zone, three of the four swamps studied emitted very little methane and only in the spring (Figure $3 b$ ). With the exception of conifer swamp 1 (Figure 3c) the fluxes were insignificant and at times the swamps acted as a methane sink. Similar to the other sites, conifer swamp 1 produced little methane for most of the summer but emitted in excess of $40 \mathrm{mg} \mathrm{CH}_{4} \mathrm{~m}^{-2} \mathrm{~d}^{-1}$ for two sample days in August. The water table in the lagg of this swamp returned to near the surface in early August.

The two thicket swamps showed very different flux levels (Figure 3c and Figure 3d). Thicket swamp 1 was the highest producing peatland of the study. The flux pattern closely followed the pattern of the peat temperatures. All fluxes were in excess of $40 \mathrm{mg} \mathrm{CH}_{4} \mathrm{~m}^{-2} \mathrm{~d}^{-1}$ and on four occasions they exceeded $120 \mathrm{mg} \mathrm{CH}_{4} \mathrm{~m}^{-2} \mathrm{~d}^{-1}$. In contrast, the flux from thicket swamp 2 was very small ( $<1 \mathrm{mg} \mathrm{CH}_{4} \mathrm{~m}^{-2} \mathrm{~d}^{-1}$ ). The seasonal pattern and magnitude of flux from the mixed (hardwood) swamps (Figure 3d) were similar to that of thicket swamp 2 but with slightly elevated fluxes in the spring.

The flux of methane from the bog was near $20 \mathrm{mg} \mathrm{CH}_{4} \mathrm{~m}^{-2}$ $\mathrm{d}^{-1}$ when the water table was at the peat surface (Figure 2) but decreased to $5 \mathrm{mg} \mathrm{CH}_{4} \mathrm{~m}^{-2} \mathrm{~d}^{-1}$ when the water dropped to -10 $\mathrm{cm}$. The fen and marsh fluxes were the most erratic of all the peatlands sampled. The flux exceeded $6 \mathrm{mg} \mathrm{CH}_{4} \mathrm{~m}^{-2} \mathrm{~d}^{-1}$ on several days, but most of the time, fluxes were near $\mathrm{OCH}_{4} \mathrm{~m}^{-2}$ $\mathrm{d}^{-1}$ (Figure 3e).

The mean seasonal flux and standard deviations, plus the maximum and minimum observed fluxes for each site sampled, are shown in Table 4. The only significant emitters of $\mathrm{CH}_{4}$ on a seasonal basis were the beaver ponds, thicket swamp 1 , conifer swamp 1, and the bog. Most of the conifer swamps, thicket swamp 2, mixed (hardwood) swamps, marshes, and the fen were all very minor sources of $\mathrm{CH}_{4}$. With the exception of the beaver ponds, conifer swamp 1, thicket swamp 1, and the bog, the other wetlands showed negative fluxes (15\%) indicating the possibility for $\mathbf{C H}_{4}$ uptake. However, caution should be used in interpreting these values. Only 46 of 313 negative fluxes measured were less than than $0.1 \mathrm{mg} \mathrm{CH}_{4} \mathrm{~m}^{-2}$ $\mathrm{d}^{-1}$, which is less than our level of detection.

\subsection{Calculation of Regional $\mathrm{CH}_{4}$ Flux}

To estimate the role of the wetlands of the Canadian low boreal forest region as a global source of atmospheric methane, the fluxes from each wetland were integrated from May 1 to November 15,1990 . It was assumed that the fluxes at the beginning and end of the study were zero. For individual wetlands that had more than one site, it was assumed that each site represented equal proportions of the wetland. When the flux from each wetland was integrated for this period, the annual flux from each wetland type (e.g. bog, fen, etc.) was computed by averaging the flux from all the wetlands in each group. The total annual flux from the fen, marshes, conifer, and mixed swamps was very small, while the bog, thicket swamps, and beaver ponds represented a significant source on a unit area basis (Table 5).

These annual fluxes were then areally weighted according to the average proportion of each wetland type, based on the four low boreal forest region surveys conducted by Riley and Michaud [1987] and Riley [1988] (Table 1). The only wetland type not surveyed by Riley was beaver ponds. The Ontario Base Map series (produced by the Ontario Ministry of Natural Resources) indicates beaver ponds when they alter the course of streams and small rivers. These high resolution maps $(1: 10,000)$ were used to calculate the area of coverage by beaver ponds for the $625-\mathrm{km}^{2}$ survey area. This area was 
TABLE 5. Areally Weighted Annual $\mathrm{CH}_{4}$ Flux for Canadian Low Boreal Wetlands According to the Wetland Fractions in Table 2

\begin{tabular}{|c|c|c|c|}
\hline Wetland Type & $\begin{array}{l}\text { Annual Integrated } \\
\text { Flux, } \mathrm{g} \mathrm{CH}_{4} \mathrm{~m}_{-2} \mathrm{yr}^{-1}\end{array}$ & $\begin{array}{l}\text { Fraction of } \\
\text { Wetland }^{\mathrm{a}}\end{array}$ & $\begin{array}{l}\text { Spatially Weighted } \\
\text { Flux, } \mathrm{g} \mathrm{CH}_{4} \mathrm{~m}^{-2} \mathrm{yr}^{-1}\end{array}$ \\
\hline Beaver ponds & 7.605 & 0.07 & 0.532 \\
\hline Conifer swamps & 0.180 & 0.41 & 0.075 \\
\hline Mixed swamps & 0.097 & 0.08 & 0.008 \\
\hline Thicket swamps & 4.748 & 0.14 & 0.665 \\
\hline Marshes & 0.110 & 0.07 & 0.008 \\
\hline Bogs & 1.746 & 0.18 & 0.314 \\
\hline Fens & 0.359 & 0.09 & 0.032 \\
\hline
\end{tabular}

The total is 1.633

${ }^{a}$ The wetland fractions vary from those in Table 1 because beaver ponds have been incorporated into the total wetland coverage.

considered representative of the mean condition of the low boreal region, since it is a relatively undeveloped area, but not in a natural preserve where the beavers are protected. Most of the low boreal region is not restricted from beaver trapping. Beaver ponds covered a total area of $6.875 \mathrm{~km}^{2}$, or $1.1 \%$ of the study area. To check the area calculated from the maps, 10 air photographs (Ontario Ministry of Environment, 1988 series) were compared to the base maps. Results from the two methods differed less than $10 \%$ in total area of beaver ponds. It was assumed that the area of beaver ponds would vary in proportion to the area of wetlands in a given survey area. Since $14.4 \%$ of the $625-\mathrm{km}^{2}$ survey area was covered with wetlands and an additional $1.1 \%$ was coverd with beaver ponds, beaver ponds comprise on average $7 \%(1.1 / 14.4 \times 100)$ of all wetlands in the area. It was assumed that this proportion was representative of the low boreal region.

The fractional area of each wetland type was multiplied by the integrated annual flux (Table 5) and a habitat-weighted annual emission of $1.633 \mathrm{~g} \mathrm{CH}_{4} \mathrm{~m}^{-2} \mathrm{yr}^{-1}$ was calculated. The area of coverage by wetlands in the entire low boreal forest region was computed by combining the wetland regions and the area of wetland coverage maps of Canada (Figure 1). The whole low boreal forest region of Canada occupies 685,501 $\mathrm{km}^{2}$, and the computed area occupied by wetlands, based on the median value of five wetland cover classes $(2.5 \%, 15.5 \%$, $38 \%, 63 \%$, and $88 \%$ ), was $91,590 \mathrm{~km}^{2}$. The total methane released from Canadian low boreal wetlands would be approximately $1.50 \times 10^{11} \mathrm{~g} \mathrm{CH}_{4} \mathrm{yr}^{-1}$, or $0.15 \mathrm{Tg} \mathrm{CH}_{4} \mathrm{yr}^{-1}$.

The calculation of regional fluxes is sensitive to two errors: (1) errors in estimates of areal coverage of each wetland type and (2) errors in the integrated annual methane flux from each wetland type. It is impossible to obtain a direct estimate of the potential size of the first error, but an anylsis of the range of error can be qualitatively evaluated. This can be accomplished by comparing the habitat-weighted annual emissions calculated for each of the four detailed survey areas used by Riley and Michaud [1987] and Riley [1988] (see Table 1). The same analysis was performed for each of these areas as was presented in Table 5, and the habitat-weighted annual emissions for Pembroke, Parry Sound, Rainy River, and Ignace were $1.389,1.380,1.797$, and $1.394 \mathrm{~g} \mathrm{CH}_{4} \mathrm{~m}^{-2} \mathrm{yr}^{-1}$, respectively. These emissions compared to that calculated for the low boreal region of Canada (Table 5) represent a range from $110 \%$ to $85 \%$, or approximately $\pm 15 \%$ error due to wetland classification.

The effect of standard error of the methane flux from individual wetland types was estimated (Table 4). This was calculated by holding the fractional area of wetland cover constant at the values presented in Table 5 and recalculating the habitat-weighted annual emissions for one stantard error above and below the mean. The emissions ranged from 1.993 to $1.304 \mathrm{~g} \mathrm{CH}_{4} \mathrm{~m}^{-2} \mathrm{yr}^{-1}$, or $\pm 21 \%$. Combining the two possible errors, the overall error could be \pm 30 to $35 \%$. Recalculating the annual methane emissions for the low boreal wetland region of Canada using the upper and lower error estimates, the flux would vary from 0.20 to $0.10 \mathrm{Tg} \mathrm{CH}_{4} \mathrm{yr}^{-1}$.

\section{DISCUSSION}

\subsection{Relationship Between Methane Flux and Environmental Variables}

Other studies [e.g. Crill et al., 1988; Moore and Knowles, 1989; Moore et al., 1990] have found that the $\mathrm{CH}_{4}$ flux from peatlands and shallow lakes are correlated with the location of the water table, the temperature of the peat or sediments [e.g. Baker-Blocker et al., 1977; Crill et al., 1988; Moore and Knowles, 1987; Moore et al., 1990], and in the case of shallow ponds, to changes in atmospheric pressure [Mattson and Likens, 1990]. The latter is the result of ebullition. Bubbling was occasionally observed from the beaver ponds.

Constancy of surface saturation was the primary variable that was associated with the higher $\mathrm{CH}_{4}$ emissions. Only two peatlands, the bog and a thicket swamp, and the beaver ponds were saturated for any length of time. All other sites including the fen, marshes, mixed and conifer swamps, and one thicket swamp were rarely saturated at the surface, and they emitted little methane. There were no significant relationships, however, between the water table and the $\mathrm{CH}_{4}$ flux. The $\mathrm{CH}_{4}$ flux was significantly correlated with peat or sediment temperature in only 3 of 24 sites. The temperature relationship occurred for only two beaver ponds $\left(r^{2}=0.21, p=0.05\right.$, slope $=5.5 \mathrm{mg} \mathrm{CH}_{4} \mathrm{~m}^{-2} \mathrm{~d}^{-1}{ }^{\circ} \mathrm{C}^{-1}$ for BP1; $\mathrm{r}^{2}=0.38, \mathrm{p}=0.05$, slope $=7.0 \mathrm{mg} \mathrm{CH}_{4} \mathrm{~m}^{-2} \mathrm{~d}^{-1}{ }^{\circ} \mathrm{C}^{-1}$ for BP3) and one thicket 


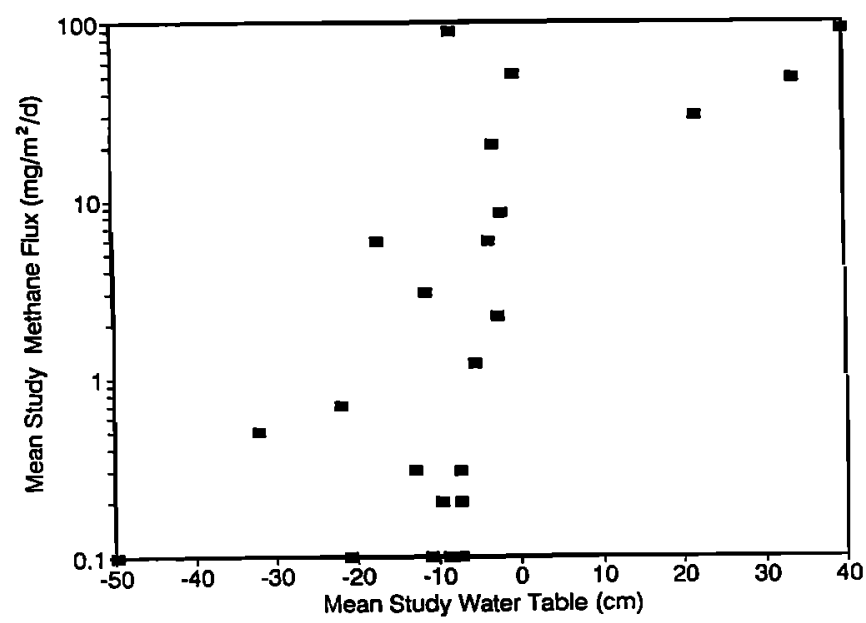

Fig. 5. Relationship between mean methane flux and mean water table location for each wetland for the study period (May - October).

swamp $\left(r^{2}=0.33, p=0.05\right.$, slope $=7.3 \mathrm{mg} \mathrm{CH}_{4} \mathrm{~m}^{-2} \mathrm{~d}^{-1}$ ${ }^{\circ} \mathrm{C}^{-1}$ ). The poor relationships indicate that no single environmental variable was a good predictor of the $\mathrm{CH}_{4}$ flux from individual wetlands.

There were a sufficient number of sites to test whether the persistent hydrological regime of a wetland was a critical factor in determining the magnitude of the mean annual $\mathrm{CH}_{4}$ flux. The seasonal mean $\mathrm{CH}_{4}$ flux from a given site (Table 4) was correlated with the seasonal mean water table location (Table 3 ) at the same site (Figure $5 ; r^{2}=0.43, p=0.05 ;$ SEE $=22$ $\mathrm{mg} \mathrm{CH} \mathrm{m}^{-2} \mathrm{~d}^{-1} \mathrm{~cm}^{-1}$, where SEE is the standard error of the estimate). The seasonal mean $-10 \mathrm{~cm}$ peat and sediment temperatures were also correlated with the seasonal mean $\mathrm{CH}_{4}$ flux from each site (Figure $6 ; \mathrm{r}^{2}=0.44, \mathrm{p}=0.05 ; \mathrm{SEE}=21.0$ $\mathrm{CH}_{4} \mathrm{~m}^{-2} \mathrm{~d}^{-1}{ }^{\circ} \mathrm{C}^{-1}$ ). Both of these relationships are, in part, driven by the extreme water table and temperature regimes of the beaver ponds, but when the regression analysis is redone with the beaver pond data removed, the correlations are still significant for water table $\left(r^{2}=0.32\right)$ and temperature $\left(r^{2}=\right.$ 0.27 ), though they are weaker. Combining the water table and temperature in a stepwise multiple regression, the water table

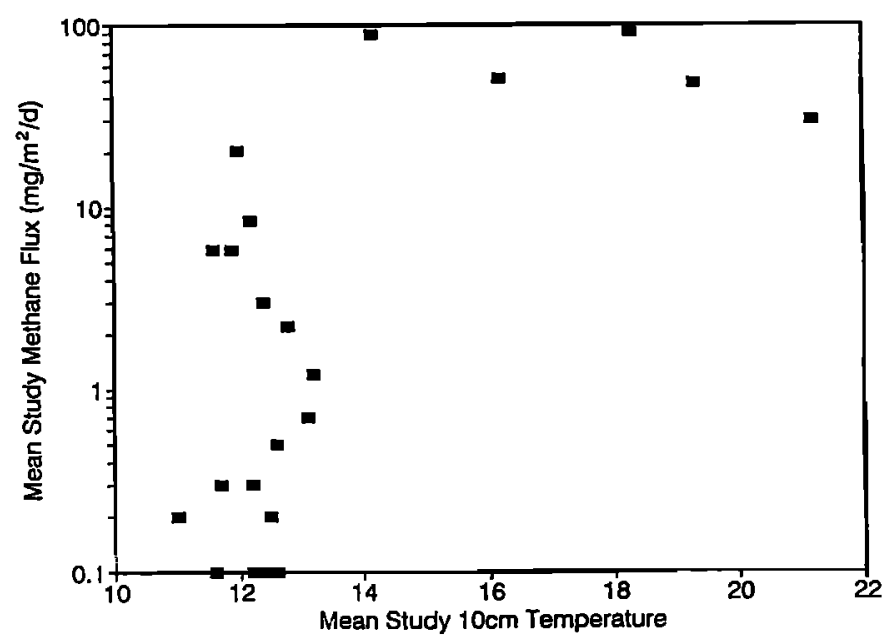

Fig. 6. Relationship between mean methane flux and mean peat/sediment temperature $(-10 \mathrm{~cm})$ for each wetland for the study period. accounted for $43 \%$ of the variation, while the peat/sediment temperature accounted for only an additional $6 \%$. The lack of increase in explanation by adding temperature is a result of the dependence of the thermal regime on the moisture condition of the peatland. The temperature of the peat and sediment is correlated with the position of the water table $\left(r^{2}=0.56, p=\right.$ 0.05 , slope $=0.1^{\circ} \mathrm{C} \mathrm{cm}^{-1}$ ), and therefore they are not independent variables. The moisture regime controls both the thermal conductivity and the heat capacity of the peat and sediment [Oke, 1987].

We believe that this is the first example of a correlation between water table and $\mathrm{CH}_{4}$ flux that holds across different wetlands in the same region. A very general relationship between peat temperature and $\mathrm{CH}_{4}$ flux across wetland types has been shown by Aselmann and Crutzen [1989]. The relationship between the flux of $\mathrm{CH}_{4}$ and the certain environmental variables within a given wetland region may be suitable for the regional extrapolation of fluxes by process-based models such as those suggested by Matson and Vitousek [1990]. Methane emissions are a function of (1) methane production in an anaerobic zone; (2) methane consumption in an aerobic zone; and (3) the transport mechanism by which methane is delivered to the wetland surface. As a result, any correlation between methane emissions and environmental variables that grossly characterizes the anaerobic and diffusive natures of wetland sediments will be inherently weak. If suitable relationships are found, there are still several requirements that are needed to make the process-based approach as operational as the linear model. To assess the feasibility of the process approach, the following advances are necessary: (1) a remote sensing tool to determine the location of the water table; (2) a larger survey undertaken over several years to reduce the standard error in the predictive model and incorporate interannual variability; and (3) a method to relate the instantaneous observations made by remote sensing to the annual or seasonal mean water table. It is very unlikely, given the overriding control of climate, that such a model would yield useful predictions over several wetland regions (e.g. temperate, boreal, and subarctic). However, process-based models would be useful because they have the potential of being intergrated into ecological and climatic models which are designed to investigate the effects of change.

\subsection{Comparison of Methane Fluxes With Other Studies and the Relative Importance of Low Boreal Wetlands as a Source of Atmospheric Methane}

The $\mathrm{CH}_{4}$ fluxes observed in this study are comparable to those from other studies of beaver ponds and bogs, but the fluxes are much lower for the swamps and fens. The mean emission rate from beaver ponds in the low boreal region of Quebee was between 140 and $162 \mathrm{mg} \mathrm{CH}_{4} \mathrm{~m}^{-2} \mathrm{~d}^{-1}$ [Ford and Naiman, 1988] and ranged from 180 to $260 \mathrm{mg} \mathrm{CH}_{4} \mathrm{~m}^{-2} \mathrm{~d}^{-1}$ for Minnesota [Naiman et al., 1991]. Higher mean rates (518 $\mathrm{mg} \mathrm{CH} \mathrm{Cm}^{-2} \mathrm{~d}^{-1}$ ) have been observed from ponds in the midboreal region [Vit et al., 1990], while a wider range of rates were found in ponds of the eastern temperate forest region (5 and $600 \mathrm{mg} \mathrm{CH}_{4} \mathrm{~m}^{-2} \mathrm{~d}^{-1}$, Yavitt et al. [1990]). The bog fluxes were typical of those found in the boreal region (< $5 \mathrm{mg} \mathrm{CH} \mathrm{m}^{-2} \mathrm{~d}^{-1}$, Moore and Knowles, [1989];0 $\mathrm{mg} \mathrm{CH}_{4} \mathrm{~m}^{-2}$ $\mathrm{d}^{-1}$. Vitt et al. [1990]) and the temperate region $(-1.1$ to $9.6 \mathrm{mg}$ $\mathrm{CH}_{4} \mathrm{~m}^{-2} \mathrm{~d}^{-1}$, Yavitt et al. [1990]). In Minnesota, Harriss et al. [1985] measured summer fluxes in the order of 156,194, and 
$419 \mathrm{mg} \mathrm{CH} \mathrm{m}^{-2} \mathrm{~d}^{-1}$ for three bogs, and Crill et al. [1988] observed fluxes of $77 \mathrm{mg} \mathrm{CH} \mathrm{m}^{-2} \mathrm{~d}^{-1}$ for treed bogs and 294 $\mathrm{mg} \mathrm{CH} \mathrm{m}^{-2} \mathrm{~d}^{-1}$ for open bogs, respectively. There appears to be no simple explanation for these larger fluxes from the Minnesota peatlands (P. Crill and E. Gorham, personal communication, 1991).

Neither the fen nor marshes were significant sources of methane. The methane flux from fens in the boreal, temperate, and subarctic regions vary considerably. $\mathrm{CH}_{4}$ emitted from poor fens is generally $<5 \mathrm{mg} \mathrm{CH}_{4} \mathrm{~m}^{-2} \mathrm{~d}^{-1}$ [Harrisset al., 1985; Yavitt et al., 1990] and between 75 and $140 \mathrm{mg} \mathrm{CH}_{4} \mathrm{~m}^{-2}$ $\mathrm{d}^{-1}$ from moderately poor fens [Crill et al., 1988; Moore et al., 1990]. The study fen was moderately poor $\left(\mathrm{Ca}-3.3 \mathrm{mg} \mathrm{L}^{-1}\right.$, $\mathrm{EC} \sim 100 \mu \mathrm{S} \mathrm{cm}^{-1}$ ) but the water table was consistently lower than observed in other studies [cf. Moore et al., 1990]. There are few data of $\mathrm{CH}_{4}$ flux from continental freshwater marshes. Salt marshes emit 2 orders of magnitude more $\mathrm{CH}_{4}$ [cf. Bartlet? et al., 1987] than was measured from this study's freshwater marshes. The fluxes observed by Vitt et al. [1990], $147 \mathrm{mg}$ $\mathrm{CH}_{4} \mathrm{~m}^{-2} \mathrm{~d}^{-1}$, and by Sebacher et al. [1986], $106 \mathrm{mg} \mathrm{CH}_{4} \mathrm{~m}^{-2}$ $\mathrm{d}^{-1}$, in boreal marshes were also 2 orders of magnitude larger than the fluxes observed in the present study.

There is a wide variety of swamps in the boreal region and although they are the most common peatland [Riley and Michaud, 1987; Riley, 1988], there are very few $\mathrm{CH}_{4}$ flux measurements from them. Part of the problem may be that some investigators may not recognize swamps as distinct from forested bogs and fens. The principal differences are the understory shrubs and peat cover. Bogs usually have a welldeveloped surface layer of Sphagnum, while the swamps are dominated by graminoids. Swamps rarely exceed 1 to $1.5 \mathrm{~m}$ of peat, while bogs can easily exceed 3 to $4 \mathrm{~m}$ [Riley, 1988]. The only directly comparable results to this study are those of Moore and Knowles [1989] for mixed and deciduous swamps in southern Quebec. When the water table was low, their swamp emissions were comparable to those of the present study $\left(0-20 \mathrm{mg} \mathrm{CH}_{4} \mathrm{~m}^{-2} \mathrm{~d}^{-1}\right)$, but when the water table was within $20 \mathrm{~cm}$ of the peat surface, the Quebec swamps emitted up to $200 \mathrm{mg} \mathrm{CH} \mathrm{Cm}_{4}^{-2} \mathrm{~d}^{-1}$. In the present study, fluxes reached only $40 \mathrm{mg} \mathrm{CH}_{4} \mathrm{~m}^{-2} \mathrm{~d}^{-1}$ at conifer swamp 1 when the surface became saturated. At the other three conifer swamps, where very little $\mathrm{CH}_{4}$ was emitted, the water table was always below the surface. There are no comparable studies of emissions from thicket and mixed swamps. The one thicket swamp that was saturated was a significant source, while the drier thicket swamp and mixed swamps were insignificant sources.

The methane emissions presented in this paper are based on measurements taken between snowmelt and the return of a snow cover in late fall. Previous studies undertaken in the subarctic have shown that methane emissions are small to nonexistent throughout the winter [Whalen and Reeburgh, 1988] and that in the spring there is a large release of methane as the peatlands melt [Moore et al., 1990; Moore and Knowles, 1990]. Recent work done in bogs and a fen of the low boreal/cool temperate region in Minnesota, suggests that winter methane flux can range between 5 and $49 \mathrm{mg} \mathrm{CH}_{4} \mathrm{~m}^{-2}$ $d^{-1}$ on average, representing between 4 and $21 \%$ of the annual flux depending on the site [Dice, 1992]. Ignoring the winter flux regime in the present study probably leads to a slight underestimate of the mean annual methane flux and annual integrated methane emission for each wetland type.

The methane emissions were integrated over the year and then linearly extrapolated to the area of the low boreal region of Canada to yield a total source estimate of $0.15 \mathrm{Tg} \mathrm{CH}_{4} \mathrm{yr}^{-1}$. This estimate was based on the areal coverage of wetlands and beaver ponds. The former was estimated from a very good data set [Riley and Michaud, 1987; Riley, 1988], but the coverage by beaver ponds is questionable. The estimate of $1.1 \%$ of the low boreal being covered by beaver ponds is an order of magnitude lower than the estimate of Naiman et. al. [1988,1991] for Minnesota and about half of that estimated by Vitt et al. [1990] for Alberta beaver ponds. Trapping is still ongoing in the low boreal region of Ontario which may reduce the population of beavers below those numbers observed elsewhere. If Naiman's [1988] areal estimate for beaver ponds was used, the total flux from the low boreal region would be $0.63 \mathrm{Tg} \mathrm{CH}_{4} \mathrm{yr}^{-1}$, with $82 \%$ of the total flux derived from beaver ponds. Using the Vitt et al. [1990] estimate, the total flux would be $0.32 \mathrm{Tg} \mathrm{CH}_{4} \mathrm{yr}^{-1}$, with $66 \%$ coming from beaver ponds. We estimate that $32 \%$ of the annual flux is provided by beaver ponds. Since the per unit area source strength for beaver ponds is large compared to other wetlands, an effort should be made to improve the estimates of pond coverage for North America.

The low boreal region of Canada comprises approximately $20 \%$ of the $3.3 \times 10^{6} \mathrm{~km}^{2}$ total boreal forest region of Canada [NWWG, 1988]. There are no comparable data for area estimates of the low boreal regions of Europe and Asia. To estimate the global coverage of low boreal wetlands, the area of the boreal forest region determined by Houghton et al. [1983],11.7 $\times 10^{6} \mathrm{~km}^{2}$, was first divided into the area of boreal wetlands given by Aselman and Crutzen [1989], 1.67 $\times 10^{6} \mathrm{~km}^{2}$, to yield a ratio of 0.14 . This ratio was then multiplied by the area of the low boreal region of Canada, divided by the total boreal region of Canada to give $3.28 \times 10^{5} \mathrm{~km}^{2}$ as a global estimate of the area of low boreal wetlands. Aselmann and Crutzen [1989] calculated the total methane emissions from the boreal region to be $17.9 \mathrm{Tg} \mathrm{CH}_{4} \mathrm{yr}^{-1}$, or $22 \%$ of the global wetland emissions. Assuming the ratio of the low boreal to total boreal area is the same globally as it is in Canada, the total global emissions from wetlands in the low boreal region should be $3.6 \mathrm{Tg} \mathrm{CH}_{4} \mathrm{yr}^{-1}$ using Aselmann and Crutzen's global estimate. Using our flux estimates, it is an order of magnitude lower at $0.54 \mathrm{Tg} \mathrm{CH}_{4} \mathrm{yr}^{-1}$. Recently, Fung et al. [1991] concluded that the northem wetland and tundra sources combined were approximately $35 \mathrm{Tg} \mathrm{CH}_{4} \mathrm{yr}^{-1}$, which is less than half their previous estimate [Matthews and Fung, 1987]. Estimates of $\mathrm{CH}_{4}$ sources have dropped significantly as more measurements from various ecosystems have been obtained and extrapolations have become more ecosystem based.

Acknowledgments. We would like to thank Lesley Rigg, Angela Travis, and Todd Kuiack for their hard work in the field, Nancy Dise for a fruitful discussion on environmental correlates, and the two anonymous reviewers for some very helpful criticisms of this manuscript. Andrew Heyes provided much assistance in the setup and operation of the gas chromatograph. Peter Dillon, Bruce Lazerte and Kevin Devito helped locate some of the study wetlands. This project was funded by NSERC Canada (STR 0045266).

\section{REFERENCES}

Aselmann, I., and P. J. Crutzen, Global distribution of natural freshwater wetlands and rice paddies, their net primary productivity, seasonality and possible methane emissions, J.Atmos. Chem., $8,307-358,1989$. 
Baker-Blocker, A., T.M. Donahue, and K.H. Mancy, Methane flux from wetland areas, Tellus, 29, 245-250, 1977.

Bartlett, D.S., K.B. Bartlett, J.M. Hartman, R.C. Harriss, D.I. Sebacher, R. Pelletier-Travis, D.D. Dow, and D.P. Brannon, Methane emissions from the Florida everglades: Patterns of variability in a regional wetland ecosystem, Global Biogeochem. Cycles, 3, 363-374, 1989a.

Bartlett, D.S., G. Sachse, P. Bakwin, K. Bartlett, D. Fizjarrald, and G. Whiting, Regional flux estimates from synthesis of enclosure, tower, and aircarft measurements, EOS Trans. $A G U, 70(3), 286$, $1989 b$.

Bartlett, K.B.,D.S.Bartlett, R.C. Harriss, and D.I.Sebacher, Methane emissions along a salt marsh salinity gradient, Biogeochemistry, 4, 183-202,1987.

Cicerone, R.J., and R.S. Omerland, Biogeochemical aspects of atmospheric methane, Global Biogeochem. Cycles, 2, 299-327,1988.

Crill, P.M.,K.B. Bartlett, R.C. Harriss, E. Gorham, E.S. Verry, D.I. Sebacher, L. Madzar, and W. Sanner, Methane flux from Minnesota peatlands, Global Biogeochem. Cycles, 2, 371-384,1988.

Crutzen, P.J., Methane sources and sinks, Nature, 350,380-381, 1991.

Dice, N., Winter fluxes of methane from Minnesota peatlands, Biogeochemistry, in press, 1992.

Energy, Mines, and Resources Canada, Canada wetland regions Map sheet 4108, National Atlas of Canada, 5th ed. Geogr. Serv. Div., Surv. and Mapp. Branch, Ottawa, Canada, 1986a.

Energy, Mines, and Resources Canada, Canada distribution of wetland - Map Sheet 4107, National Atlas of Canada, 5th ed., Geogr. Serv. Div., Surv. and Mapp. Branch, Ottawa, Canada, 1986b.

Energy, Mines, and Resources Canada, Climatic regions of Canada Map sheet 4155 and 4096F, National Atlas of Canada, 5th ed., Geogr. Serv. Div.,Surv. and Mapp. Branch, Ottawa, Canada, 1990.

Ford, T.E., and R.J. Naiman, Alteration of carbon cycling by beaver: Methane evasion rates from boreal forest streams and rivers, Can. J. Zool. , 66, 529-533, 1988 .

Fung, I., J. John, J. Lerner, E. Matthews, M. Prather, L.P. Steele, and P.J. Fraser, Three-dimensional model synthesis of the global methane cycle, J. Geophys. Res., 96(D7), 13,033-13,065,1991.

Harriss, R.C., E. Gorham, D.I. Sebacher, K.B. Bartlen, and P.A. Flebbe, Methane flux from northern peatlands, Nature, 315,652 $654,1985$.

Houghton, R.A., J.E. Hobbie, J.M. Mellio, B. Moore, B.J. Peterson, G.R. Shaver, and G.M. Woodwell, Changes in the carbon content of terrestrial biota and soils between 1860 and 1980: A net release of $\mathrm{CO}_{2}$ to the atmosphere, Ecol. Mongr.,53,235-262,1983.

Matthews, E., and I. Fung, Methane emissions from natural wetlands: Global distribution, area, and environmental characteristics of sources, Global Biogeochem. Cycles, 1, 61-86, 1987.

Mattson, M.D., and G.E. Likens, Air pressure and methane flux, Nature, 347, 718-719,1990.

Matson, P.A., and P.M. Vitousek, Remote sensing and trace gas fluxes, in Remote Sensing of Biospheric Function, edited by R.J. Hobbs, and H.A. Mooney, pp. 157-167, Springer-Verlag, New York, 1990

Moore, T.R., and R. Knowles, Methane and carbon dioxide evolution from subarctic fens, Can. J. Soil Sci., 67, 77-81, 1987.

Moore, T.R., and N.T. Roulet, A comparison of dynamic and static chambers for methane ernission measurements from subarctic fens, Atmos. Ocean, 29, 102-109, 1991.

Moore, T.R., and R. Knowles, Methane emissions from feri, bog, and swamp peatlands in Quebec, Biogeochemistry, 11, 45-61, 1990.

Moore, T.R., and R. Knowles, The influence of water table levels on methane and carbon dioxide ernissions from peatland soils, Can. J. Soil Sci., 69, 33-38, 1989.

Moore, T.R., N.T. Roulet, and R. Knowles, Spatial and temporal variations of methane flux from subarctic/northern boreal fens, Global Biogeochem. Cycles, 4, 29-46, 1990.

Naiman, R.J., C.A. Johnston, and J.C. Kelley, Alteration of North American streams by beaver, BioScience, 38, 753-762, 1988.

Naiman, R.J., T. Manning, and C.A. Johnston, Beaver population fluctuations and tropospheric methane emissions in boreal wetlands, Biogeochemistry, 12, 1-15, 1991.

National Wetlands Working Group (NWWG), Wetlands of Canada, Ecol. Land Cl. Ser., vol. 24,452 pp., Environment Canada, Ottawa, Ontario, and Polyscience Publications Incorporated, Montreal, Quebec, Canada, 1988.

Novak, M., Wild Furbearer Management and Conservation in North America, 1150 pp., Ontario Trapping Association and Ontario Ministry of Natural Resources, Toronto, Canada, 1987.

Oke, T., Boundary Layer Climatology, 2nd Ed., 435 pp., Methuen, New York, 1987.

Riley, J.L, Peat and peatland resources of southeastern Ontario, 283 pp., Mines and Minerals Division, Ontario Geological Survey, Ontario Ministry of Northern Development and Mines, Open File Rep. 5633, 1988.

Riley, J.L., and L. Michaud, Peat and peatland resources of north western Ontario, 275 pp., Mines and Minerals Division, Ontario Geological Survey, Ontario Ministry of Northern Development and Mines, Open File Rep. 5632, 1987.

Roulet, N.T.,The Role of the Hudson Bay lowland as a global source of atmospheric methane, Eos Trans. AGU, 72(17), 84, 1991.

Sebacher, D.I., R.C. Harriss, K.B. Bartlett, S.M. Sebacher, and S.S. Grice, Atmosphere methane sources: Alaskan tundra bogs, an alpine fen, and a subarctic boreal marsh, Tellus, 38(B), 1-10, 1986.

Vitt, D.H., S. Bayley, T. Jin, L. Halsey, B. Parker, and R. Craik, Methane and carbon dioxide production from wetlands in boreal Alberta, report contract 90-0270, Alberta Environ. Minist., Edmonton, Canada, 1990.

Whalen, S.C. and W.S. Reeburgh, A methane flux time series for tundra environments, Global Biogeachem. Cycles, 2, 339-409,1988.

Yavitt, J.B., G.E. Lang, and A.J.Sexstone, Methane fluxes in welland and forest soils, beaver ponds, and low-order streams of a temperate forest ecosystem, J. Geophys. Res., 95(D13), 22,463$22,474,1990$.

R. Ash and N.T. Roulet, Department of Geography, York Univeristy, 4700Keele Street, North York, Ontario, Canada M3J 1 P3. T.R. Moore, Department of Geography, McGill University, 805 Sherbrooke Street W., Montreal, Quebec, Canada H3A 2K6.

(Received September 16, 1991; revised December 10, 1991; accepled December 10,1991.) 